\title{
REDUCING THE THREAT: THE POTENTIAL USE OF PHEROMONES TO CONTROL INVASIVE SIGNAL CRAYFISH
}

\author{
P.D. STEBBING (1)*, G.J. WATSON (2), M.G. BENTLEY (1), D. FRASER (3), \\ R. JENNINGS (4), S.P. RUSHTON (5), P.J. SIBLEY (6)
}

(1) School of Marine Science and Technology, Ridley Building, University of Newcastle, Newcastle upon Tyne, NE1 7RU, UK.

(2) Institute of Marine Sciences, School of Biological Sciences, University of Portsmouth, Ferry Road, Eastney, Portsmouth, PO4 9LY, UK.

(3) English Nature, Northminster House, Peterborough, PE1 1AU, UK.

(4) Environment Agency (North East Region), 1 Viking Close, Great Gutter Lane (East), Willerby, Hull, HU10 6DE, UK.

(5) Centre for Land Use and Water Resources Research, Porter Building, St. Thomas Street, University of Newcastle, Newcastle upon Tyne, NE1 7RU, UK.

(6) Environment Agency (South West Region), East Quay, Bridgwater, Somerset, TA6 4YS, UK.

* To whom correspondence should be addressed: P.D.Stebbing@ncl.ac.uk Telephone: +44 (0) 191222 6661; Fax: +44 (0) 1912227891

Reçu le19 juillet 2003

Received July 19, 2003

Accepté le 22 janvier 2004 Accepted January 22, 2004

\section{ABSTRACT}

The need for an effective method of controlling invasive species of crayfish is of utmost importance given the plight of Europe's native crayfish species. Many techniques have been applied to the growing problem with little success.

Pheromones have been used to control terrestrial insect pests for a number of years with many success stories. The concept of applying pheromone control methods to the aquatic environment is by no means new, but has not been previously developed.

This paper discusses the preliminary results from field trials testing traps baited with Pacifastacus leniusculus pheromones, and the potential application of the pheromones in controlling $P$. leniusculus populations.

Key-words: Signal Crayfish, Pacifastacus leniusculus, invasive species, control methods, pheromones. 


\section{RÉDUIRE LA MENACE : UTILISATION POTENTIELLE DE PHÉROMONES POUR CONTRÔLER LES ÉCREVISSES «SIGNAL » INVASIVES}

\section{RÉSUMÉ}

Compte-tenu de la peste qui décime les espèces d'écrevisses européennes natives, il est d'une extrême importance de définir une méthode efficace de contrôle des espèces invasives d'écrevisse. De nombreuses techniques ont été tentées pour lutter contre ce problème grandissant, avec peu de succès.

Les phéromones sont utilisées depuis de nombreuses années avec succès dans le contrôle d'insectes terrestres nuisibles. L'idée d'appliquer au milieu aquatique des méthodes utilisant des phéromones n'est pas nouvelle, mais n'a pas jusqu'alors été développée.

Cet article présente les résultats préliminaires de campagnes de tests sur le terrain de pièges appâtés avec des phéromones de Pacifastacus leniusculus, et débat de l'application potentielle de phéromones pour contrôler les populations de $P$. leniusculus.

Mots-clés : écrevisse Signal, Pacifastacus leniusculus, espèce invasive, méthodes de contrôle, phéromones.

\section{INTRODUCTION}

"One of the major threats to native biological diversity is now acknowledged by scientists and governments to be biological invasions caused by alien invasive species" (IUCN, 2000), this is typified in the decline of Britain's native white-clawed crayfish (Austropotamobius pallipes) caused by the presence of the signal crayfish (Pacifastacus leniusculus), originally from North America. Not only is $P$. leniusculus a threat to $A$. pallipes through direct and indirect competition, but it also acts as a vector for the Crayfish Plague (Aphanomyces astaci), which is lethal to A. pallipes (HOLDICH, 1999).

The search for a method to eradicate $P$. leniusculus has to date been fruitless and, as a result, there has been an unabated spread of the species throughout waterways of mainland Britain and much of Europe. Many scientists now feel that eradication of such a widely established and aggressive species is impossible. The need, however, to protect existing populations of $A$. pallipes from $P$. leniusculus either through control or containment is of the utmost importance.

Despite the urgent need for an effective control method, the requirements of such a method have remained constant (IUCN, 2000): "The control method should be socially, culturally and ethically acceptable, efficient, non-polluting, and should not adversely affect native flora and fauna, human health and well-being, domestic animals, or crops". Finding a control method that meets all of the above criteria and which is effective is proving difficult. Our efforts over the past 2 years have focused on the use of crayfish pheromones as a possible form of control. Pheromones have been used in the past to help in the management of terrestrial insect pests. The idea that this technique, already widely used to control insect pests, might find application in the control of aquatic pests is not new and has been around for several years (BENTLEY and WATSON, 2000), although to the best of our knowledge it has not been developed previously.

In this paper we discuss the potential of pheromone-baited traps as a management tool in the control of $P$. leniusculus and the potential uses of the technique. 


\section{METHODS AND MATERIALS}

Sex, stress and alarm pheromone water was freeze-dried and placed in slow release gels. Blank slow release gels and $25 \mathrm{~g}$ of smoked mackerel were used as negative and positive controls, respectively. These were tested in the field using standard cylindrical crayfish "Trappy" traps. Twelve traps were deployed for each treatment. The female sex pheromone had been shown only to be released and only to exert an effect on males during the breeding season and so were tested exclusively during this period (STEBBING et al., 2003a). Stress and alarm pheromones have been shown to be released and exert an effect all year round and so were tested in the field at varying times of the year (pers. obs.). The stress and alarm baited traps also contained $25 \mathrm{~g}$ of smoked mackerel; this was so the effect of the pheromone could be tested by comparing the total number of animals in the pheromone trap to that of a normal food baited trap. As this paper mainly wishes to discuss the application of pheromone-baited traps rather than the development and protocols for the deployment of the traps, a full explanation of these can be found in STEBBING et al. (2003b). The mean catch per treatment for the preliminary field trials is shown in Figure 1 (with 95\% confidence intervals) and were analysed using a general linear model with a pair-wise comparison, at the 95\% significance level (CONOVER and IMAN, 1981).

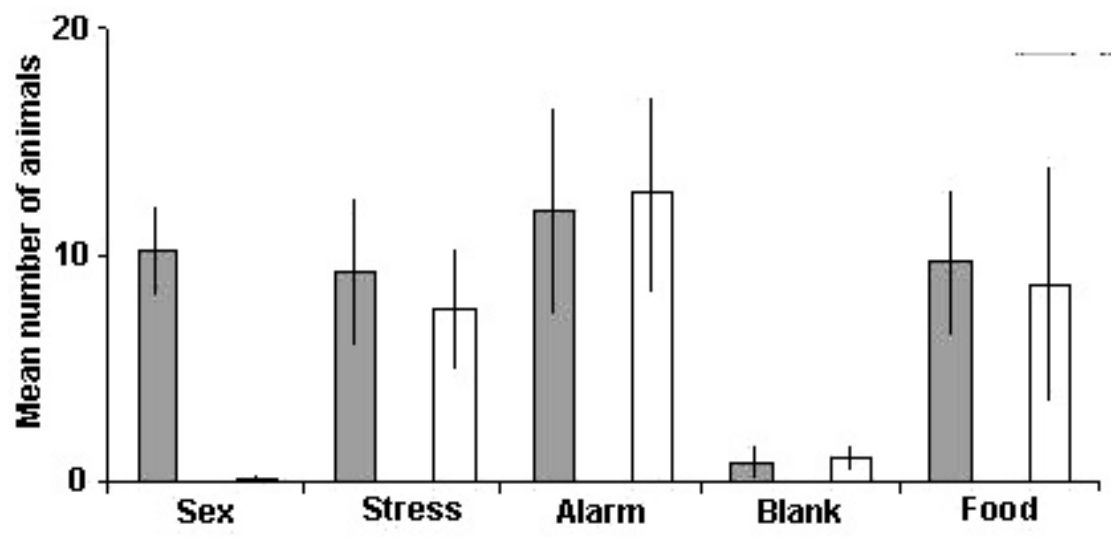

Figure 1

Mean number of male (grey) and female (white) $P$. leniusculus caught in each treatment (12 traps per treatment), Mean $+/-95 \%$ confidence intervals.

\section{Figure 1}

Effectif moyen de mâles (en gris) et de femelles (en blanc) de $P$. leniusculus capturés dans chaque traitement (12 pièges par traitement), Moyenne $+/-95 \%$ d'intervalle de confiance.

\section{RESULTS}

Figure 1 shows the results from the first trapping trials, the grey bars show the mean number of males in each trap and the white show the mean number of females in each trap with $95 \%$ confidence intervals $(\mathrm{N}=12$ for each treatment). It is clear that the sex pheromone baited traps attract mostly males (males vs. females, T - 7.287, P 0.0000), with on average 10.25 males in each trap compared to 0.167 females. No significant difference was seen in the number of males compared to females in any of the other treatments. There was also no significant difference in the number of males found in the sex pheromone baited traps compared to the number of males in the other treatments, 
save for the blank traps (sex (male) vs. blank (male), T - 6.590, P 0.0000) where there was significantly more males in the sex pheromone traps. All treatments had significantly more animals in the blank treatments, showing that the slow release gel itself does not attract animals. There were significantly more animals found in the alarm pheromone baited traps than in the sex pheromone baited traps (sex vs. alarm, T 3.535, P 0.0380), but no significant difference was found between sex and stress pheromone baited traps (sex vs. stress, T 2.543, P 0.4165), or between the stress and alarm traps (stress vs. alarm, T 0.992, P 0.9996). There were no significant differences between the total numbers of animals found in the stress or alarm pheromone baited traps when compared to the food baited traps (stress vs. food, T 2.129, P 0.7138; alarm vs. food, T - 0.414, P 1.0000).

\section{DISCUSSION}

The idea behind the development of traps baited with stress and alarm pheromones was to produce a trap that $P$. leniusculus found repellent, this would allow a population's movement to be restricted or to drive animals into areas to make trapping easier (HOLDICH et al., 1999). Despite laboratory-based trials demonstrating that stress and alarm pheromones repel conspecifics, traps baited with these pheromones do not seem to repel animals in the field. However, due to the lack of significant differences between the traps baited with stress and alarm pheromones and those baited with food suggest that the pheromone is not having any effect on the number of animals entering the trap. There are a number of possibilities for the stress and alarm pheromone traps not working in the field: the pheromone may not have been released from the gel at a high enough concentration to have an effect, the associated food bait may have been more attractive to the animals than the pheromone was repellent, or the pheromone was not released at a steady rate from the gel; all the pheromone may have been released at the beginning of the 24 hour trial, this would still leave the food bait in the trap attracting animals. Further development of these baits has been stopped so that work can focus on the sex pheromone baited traps that showed more promising results.

The lack of a significant difference between the numbers of males between treatments (save for the blank gel control and other treatments) suggests that there is a maximum carrying capacity for males for the type of trap used in the trials. This could be due to the size of the trap restricting the number of animals that fit into the trap. The aggressive nature of male $P$. leniusculus may also restrict the number of other conspecifics that will approach the trap once males have entered the trap. Development of new design of traps that may overcome these problems is being carried out.

The results show that the sex pheromone baited traps are as attractive to males during the breeding season as normal food baited traps are to both sexes. With further refinement of the methodology it is hoped that the sex pheromone baited traps could be made even more attractive. The sex pheromone baited traps only attract males and will only work during the breeding season when the males are sensitive to the female released sex pheromone. Although there is a restricted temporal window for effective trapping using sex pheromone baited traps, the power of the technique lies in its sex specificity. Food baited traps will reduce the population numbers but unless the population is eradicated a smaller number of individuals would have less competition for resources and have the potential to recover quickly. In contrast, the removal of large numbers of mature males during the breeding season could effectively shift the sex ratio, whilst the remaining females would continue to experience inter-individual competition for resources. In theory the reduction in size of the male breeding population would stimulate animals to mature at an earlier age (HOLDICH et. al., 1999), this would mean that they would become receptive to the pheromone and so more readily trapped at a smaller size (given minor modifications to the traps being used). An ultimate goal would be to leave a non-breeding population 
of females. Sex pheromone baited traps have been used as breeding disruptors in terrestrial pest management with animals that have an equally limited breeding season. The use of sex pheromone baited traps coupled with year round trapping using normal food baited traps removing females and males of both juvenile and adult life stages could potentially restrict the growth rate and even reduce the size of a Pacifastacus leniusculus population.

A further advantage of use use of sex pheromone traps is that, because of the species specificity of sex pheromones (pers. obs.), the removal of $P$. leniusculus could be carried out in the presence of native white-clawed crayfish $A$. pallipes (or other crayfish species). This would allow extensive trapping of a mixed population causing minimal disturbance to $A$. pallipes whilst only removing the targeted species.

Sex pheromone trapping could also be used to detect low densities of crayfish that would otherwise not be detectable by using normal food baited traps. The ability to detect the absence or presence of a population at low densities would be useful as an "early warning" technique which would allow managers to take measures to prevent the establishment of the population.

The preliminary results of the field trial suggest that pheromone baited traps could have a number of applications. However, it must be stressed that the development of this technique is very much in its infancy and a lot more work is required before this tool will be available. Sex pheromone trapping should be viewed as another potential aid in the control of $P$. leniusculus and with further development, pheromone baited traps could be a valuable means by which the threat of $P$. leniusculus to native species of crayfish could be reduced.

\section{ACKNOWLEDGEMENTS}

The authors acknowledge financial support from English Nature and the Environment Agency through Research Contract EIT 30-05-12.

\section{REFERENCES}

BENTLEY M. G. AND WATSON G. J., 2000. Making scents of sex underwater. Biologist, 47, 251-254.

CONOVER W.J. and IMAN R.L., 1981. Rank transformations as a bridge between parametric and non-parametric statistics. The American Statistician 35, 124-133.

HOLDICH D.M., 1999. The negative effects of established crayfish introductions. In Crayfish in Europe as alien species. How to make the best of a bad situation? GHERARDI F. and HOLDICH D. (Eds.), 31-47. A.A. Balkema, Rotterdam.

HOLDICH D.M., GYDEMO R. and ROGERS W.D., 1999. A review of possible methods of controlling nuisance populations of alien crayfish. In Crayfish in Europe as alien species. How to make the best of a bad situation? GHERARDI F. and HOLDICH D. (Eds.), 245-270. A.A. Balkema, Rotterdam.

I.U.C.N., 2000. Guidelines for the prevention of biodiversity loss caused by alien invasive species. Fifth meeting of the Subsidiary body on Scientific, Technical and Technological Advice. Montréal, Canada 31 January-4 February, 2000. Available at: http://www.iucn.org/themes/biodiversity/sbstta5/guidelines invasive.pdf

STEBBING P.D., BENTLEY M.G. \& WATSON G.J., 2003a. Mating behaviour and evidence for a female released courtship pheromone in the signal crayfish Pacifastacus leniusculus. Journal of Chemical Ecology, 29(2), 463-473. 
STEBBING P.D., WATSON G.J., BENTLEY M.G., FRASER D., JENNINGS R., RUSHTON S.P., SIBLEY P.J., 2003b. Chemical Ecology: a Role in the control of invasive crayfish? In Management and Conservation of Crayfish. Proceedings of a conference on $7^{\text {th }}$ November 2002, HOLDICH D. and SIBLEY P. (Eds.), 175-184. Environment Agency, Bristol. 